\title{
Corporate Governance in the Banking Sector (Empirical Study on the Effect of Separating Chairman and Chief Executive Officer (CEO) Positions on Financial Performance)
}

\author{
Ayman Mohamed Zerban ${ }^{1} \&$ Wael Bahaa El Din Ateia ${ }^{2}$ \\ ${ }^{1}$ Department of Accounting, College of Business Administration, University of Business and Technology, Jeddah, \\ Saudi Arabia \\ ${ }^{2}$ Commercial International Bank, Alexandria, Egypt \\ Correspondence: Ayman Mohamed Zerban, Department of Accounting, College of Business Administration, \\ University of Business and Technology, Jeddah, Saudi Arabia
}

Received: April 16, 2016

Accepted: June 18, 2016

Online Published: June 24, 2016

doi:10.5430/afr.v5n3p37

URL: http://dx.doi.org/10.5430/afr.v5n3p37

\begin{abstract}
The subject of corporate governance has brought great attention to global business in developing and developed countries after a string collapses of high profile companies. The failure of Enron Corporation in 2001 for example shocked the investment community in it very core. Banking sector is a critical sector in any economy. A well-developed corporate governance system with clear authorities and responsibilities can contribute in advancing economic welfare. Good corporate governance enhance real investments. At the core of corporate governance lies the importance of transparency, monitoring, responsibility and accountability.

Egypt is one of the most important Arab countries. Now the Egyptian uprising has to bring into attention economic as well as political reform. The failure of the privatization program together with the lack of rules governing organizations and institutions stress the need for reform. Effective corporate governance practices are essential for achieving and maintaining public trust and confidence in the banking system.

The objective of this study is to investigate and explore the effect of separation the positions of CEO and Chairman on the financial performance of banks in Egypt. We believe that this research could be beneficial as it shed light on new, empirical knowledge on the effect of separation positions of Chief Executive Officer and Chairman on a developing country such as Egypt struggling to achieve high rates of economic growth by creating a well-developed legal, political and economic infrastructure. The empirical study on Egyptian commercial banks measures financial performance by return on assets (ROA) and return on equity (ROE) since both ratios summarize the final results of the bank performance.
\end{abstract}

Keywords: Corporate governance, Banking Sector, Egypt

\section{Introduction}

The failure of Enron Corporation in 2001 was the fuel that inflamed the importance of corporate governance in developed and developing countries with different degrees. It showed the flawed of our accounting and auditing systems as well as shortages in rules governing organizations with the greed of corporate managers.

Corporate governance of banks in developing countries such as Egypt is important as banks have great role in developing economy financial systems, and are extremely important engines of economic growth. Financial markets in developing countries are usually underdeveloped, banks are typically the most important source of finance for the majority of companies. Banks are usually the main depository channel for the economy's savings. Many developing countries have recently liberalized their banking systems through privatization and reduce the role of government in financial regulation. Consequently, managers of banks in economies such as Egypt have obtained greater freedom in how they run their banks.

Banks are different from that of non-financial institutions. Banks have many stakeholders which creates more challenges than non-financial institutions. Business of banks is complicated and can shift rather quickly due to many factors. Stakeholders in a bank include debtholders, the majority of which are the depositors. The failure of banks can creates huge consequences to financial system of the country concerned as a whole (Mehran et al., 2011). As pointed 
by Narwal and Jinda (2015, p.81) "Poor corporate structure results indiscipline, both on the part of management and workers. Poorly governed corporations not only pose a risk to themselves, but they also cause barrier to others and could indeed pull down capital markets". The collapse of banks creates social costs to stakeholders and sometimes bank mangers in their desire to satisfy shareholders can bear more financial risk which exposed stakeholders to financial disasters (Marcinkowska, 2012). The objective of this study is to investigate and explore the effect of separation the positions of CEO and Chairman on the financial performance of banks.

\subsection{Problem Statement}

The duality of Chairman/CEO is considered a debated area in research (Narwal and Jindal, 2015). The CEO a leader is responsible for implementing short and long term plans as well as the effective running of business. On the other hand, the chairman is responsible for ensuring that the board works as it should in monitoring the CEO to ensure that shareholder interest is well protected. As stated by Tonello (2011, p.1), "In light of required disclosure about board leadership structure, the decision of whether or not to separate the chairman and chief executive roles remains a hot governance topic for public companies, boards and shareholders". Since the chairman performs important control functions, it is often suggested that a separate person apart from the CEO should occupy this position. The Chairman/CEO duality can creates obstacle for the board's ability to perform its monitoring functions over CEO. Likewise, Jensen (1993) argues that separating the two positions is required for board effectiveness. According to stakeholders theory which provides theoretical framework for analyzing relations between companies and society, companies should design their strategies considering their stakeholders. This contrast the shareholders perspective which implies that managers should be controlled by the board to act on the owner's interest. While the mode of governance according to stakeholders perspective is to maintain more coordination, collaboration and conflict resolution in order to distribute value among stakeholders (Ayuso and Argandona, 2007) .

This research thus seeks to investigate and explore the effect of separation the positions of CEO and Chairman on the financial performance of banks measured by return on assets and return on equity in Egypt by examining the following research question:

- Is the separation positions of Chief Executive Officer and Chairman has an impact on the financial performance of Egyptian banks?

\subsection{Literature Review}

Banks are essential for the effective functioning in any economy. Effective corporate governance practices are necessary. Banks failure is inevitable with poor corporate governance (Bank for International Settlements, 2006). Black et al., (2006) provide evidence that corporate governance is an important factor in explaining the market value of Korean public companies, and that this effect is likely causal. Companies' having higher governance scores have a high market value. According to Russell Reynolds Associates survey (2012) recent corporate financial scandals have created a need for intensifying corporate governance, including calls for the separation of CEO and chairman positions. Indeed, from 2001 to 2005 companies included in the Standard \& Poor's 500, and NASDAQ 100, started to separate the Chairman and CEO positions.

The concept of corporate governance takes into consideration the relationship between stakeholders and management of companies. This relationship has to be based on trust and credibility and to be sustainable. The overall objective for the shareholders is to have adequate return on their investments. Therefore, the owners must be sure that management are going to work in their best interest since they are the ones operating their investment. It is the management that are managing the owners' capital and are in some ways responsible for making sufficient return. Shareholders' interests may differ from those of other stakeholders, especially on risk tolerance (Mehran et al., 2011). Macey and O'Hara (2003) argue corporate governance mechanisms for banks should include depositors and shareholders. The complexity of banks operations also makes it very costly for depositors to control managers. Depositors need to be sure when the deposit their money in banks. Governments through insurance and regulations can encourage depositors and make them safer. According to (Bank for International Settlements, 2006) the effectiveness of the board of directors require identifying lines of authority, responsibility and accountability for managers and be able to oversight their decisions. The relationship between management and owners are discussed in the agency theory. The agency theory, developed by Jensen and Meckling (1976), highlights the existing conflict of interests between the owners of a company and its management. Agency theory suggest that CEO duality may limit board's ability to monitor management and thereby increase the agency cost. As a result, splitting the titles of CEO and Chairman of the Board will improve firm performance. On the other hand, Dahya et al., (2009) conducted a study to examine the performance of UK public listed companies after the issuing of Cadbury Committee's Code of Best Practice. They found no significant improvement for companies separating chief executive officer and chief of the board positions. 
Corporate governance is a mechanism through which shareholders are assured that managers will act in their interests. Sometimes managers do not always act in the best interests of shareholders. Suppliers of finance control managers in order to ensure that their capital is not going to vaporize and that they earn a reasonable return on their investment. Nevertheless, even if the government provides deposit insurance, bank managers may be involved in risky projects with the aim of high return. Regulations are necessary to limit bank manager's strive for high returns. Therefore the special nature of the banking industry requires protection of depositors from bank management (Capiro and Levine, 2002). Shareholders may want managers to take more risk than is socially optimal, whereas regulators have a preference for managers to take substantially less risk due to their concerns about financial stability. Good corporate governance can help to prevent corporate scandals. It enhances image and reputation of financial institutions and makes them more attractive to stakeholders. The implementation of corporate governance principles such as disclosure of information, protection of shareholder rights and equal treatment of shareholders, can ensures safeguarding of investments (Todorovic, 2013). Usui (2003) argued that both American and Japanese bank regulators have high authority to supervise and inspect banking organizations. Sarbanes-Oxley Act and new provisions in Japanese Commercial Code have a common trend in which they all consider the oversight of the board of directors and senior management as the key to the improvement of corporate governance. Both were enacted with the purpose of protecting investors and are applicable not only to banking organizations but to all businesses. In addition to the enactment of the corporate governance laws, American and Japanese bank regulators are continuing to create new regulations and guidelines on banking organizations' corporate governance. Arun and Turner (2004) argued for the need of corporate governance in the banking sector to protect depositors. It is necessary to have supervisor authority and to work closely with bank's management. One of the most hotly issues in corporate governance is the question of whether the chief executive officer (CEO) should also serve as the chairman of the board of directors. Tonello (2011, p.1) argued that "when, as after the recent financial crisis, public corporations come under fire from activist shareholders, institutional investors, proxy advisory firms, and regulators, the issue of separating the Chair/CEOs roles is often front and center, with a view to achieving independent leadership in the board". Recent corporate scandals created debates on the effectiveness of corporate governance and the accountability of corporate executives. The CEO is a corporation's chief strategist, responsible for initiating and implementing company-wide plans and policies. The Russell Reynolds Associates' Survey New York (2012) highlighted that board members are concerned about their independence from the Chief Executive and are increasingly promoting that the chairman and CEO roles be separated to have a balance of power. While this trend is more established in Europe, data indicates that companies in the United States are imitating. While the trend toward separating the roles gains prominence, not all directors are in favor. According to survey, $41 \%$ percent of board members feel the chairman/CEO position should be one person.

Kang and Zardkoohi (2005) concluded that the relationship between CEO/Chair is complex due to turbulence in the external environment and if such duality exists as a reward, it might result in positive performance. But if the reason is to increase the CEO's power than it may have a negative effect on the performance of the firm. If duality contributed to corporate scandals, it is not the only reason to cause corporate failure.

The evaluation of the Egyptian financial sector before 2004 urges the need for reforming financial sector regulation and supervision. The Program was approved in September 2004, and is currently under implementation. According to African Development Bank Group (2012, p.4 emphasis added) case study about Egypt financial sector reform program:

The development of secondary capital markets will improve price discovery and valuation of financial assets and productive activities, and will improve liquidity by facilitating efficient capital entry and exit. The buildup in regulatory and supervisory capacity with enhanced corporate governance will ensure market integrity and instill investor confidence. The creation of a mortgage market will serve as a market mechanism for mobilizing medium-term funding from capital markets for residential housing while increasing access to finance and affordability.

As a further step to strengthen the banking sector, the Banking Reform Unit (BRU) - a unit reporting to the Deputy-Governor- was established at the Central Bank of Egypt (CBE, hereafter). The Banking Reform Unit worked out on a basis of four pillars (CBE, 2007):

- $\quad$ Privatization and consolidation of the banking sector;

- Streamlining the financial and managerial structure of State-owned banks;

- $\quad$ Addressing the issue of non-performing loans;

- Upgrading CBE banking supervision. 
The CBE works on deepening and developing the concept of risk- based supervision, in order to assess banks' ability to identify, measure, control and manage current and future risks. The CBE also examines the adequacy of procedures and internal control systems applicable at banks to determine, measure and control the information technology related risks. During the financial year 2005/2006, examinations covered 16 banks. To effect the provisions of Article 133 of Law No. 88 for 2003, of the Central Bank, many settlement cases are studied, and their settlement reports are documented. In addition, the CBE co-operates with any investigation entities that need banking expertise and know how assistance to decide on the relevant technical banking issues. In addition, the CBE studies customers' complaints to verify them. Moreover, the CBE's Board approved in its session on February 7, 2006 Decision No. 305 regarding the maximum limits of a bank's investments with a single customer and the connected parties (CBE, 2006).

Banks' aggregate financial position during 2005-2007 shows an increase over the three years following the implementation of the reform program.

Table 1. Aggregate Financial position of Banks (CBE, 2007)

\begin{tabular}{|c|c|c|c|}
\hline Fod of Jume & 2005 & 2006 & 2007 \\
\hline Cash & 6594 & 6813 & 7705 \\
\hline Securities and investments & 170659 & 193965 & 176098 \\
\hline Balances With banks abroad & 51204 & 72554 & 124366 \\
\hline Balances with the CBE & 109773 & 109597 & 199542 \\
\hline Balances with local banks & 15213 & 12098 & 17821 \\
\hline I oan and discount balances & 308195 & 324041 & 353746 \\
\hline Other assets & 41990 & 42494 & 58645 \\
\hline (Assets = Liabilities) & 703628 & 761562 & 937923 \\
\hline Capital & 22949 & 27112 & 33037 \\
\hline Reserves & 12419 & 13418 & 12552 \\
\hline Provisions & 49541 & 54950 & 53469 \\
\hline Bonds and lons-tenm loans & 14254 & 17526 & 26351 \\
\hline Obligations to banks abroad & 12262 & 8770 & 10006 \\
\hline Obligations to the CBE & 8011 & 10379 & 66485 \\
\hline Obligations to local banks & 14660 & 11109 & 16134 \\
\hline Deposits & 519649 & 568841 & 649953 \\
\hline Other liabilities & 49883 & 49457 & 69936 \\
\hline
\end{tabular}

Source : CBE (2007)

As per Central bank of Egypt Annual Report 2007, the level of profits realized by a bank reflects its ability to strengthen its capital (equities) and to distribute dividends among its shareholders. A follow up of the levels of banks' profits reveals that public sector banks net profits amounted to some LE 2204 million for the year ending June $30^{\text {th }}$, 2006, (mainly due to the profits of selling some of financial investments held with the Bank of Alexandria) compared with LE 714 million for the previous financial year. The ratio of public sector banks' average return on equity was 11.6 percent for the year ending June $30^{\text {th }}$, 2006, against 3.9 percent for the preceding year (CBE, 2007).

We believe that this research could be beneficial since it provides new, empirical knowledge on the effect of separation positions of CEO and Chairman on the financial performance of the Egyptian banks. The objective of this study is to investigate and explore the effect of separation the positions of CEO and chairman on the financial performance of banks in Egypt. The main objective is to find out whether there is a correlation between separation of the two positions Chairman and CEO's in achieving better financial performance reflected in better financial ratios of return on assets (ROA) \& return on equity (ROE).

\subsection{Hypotheses}

This research will take both an explorative and a descriptive approach. It will take an explorative approach because it provides basic knowledge concerning the concepts of corporate governance as well as special aspects of corporate governance for banking sector. The descriptive approach is based on a description of how the financial performance of banks in Egypt affected by separation CEO and chairman positions, thus we took the descriptive approach to gather data, analyze it and interpret it. We proposed the following hypotheses for the concern of this research:

H1: There is a positive correlation between separation chairman \& CEO positions and enhancing return on assets (ROA) \& return on equity (ROE) in Egyptian banks.

\section{Methodology}

Our empirical study data collection and analysis was built on 3 years period financial statements $(2005,2006$, and 2007) of the sample selected banks. In September 2004 the Government of Egypt launched a comprehensive reform programmer for its financial sector. It is, Financial Sector Reform Program, planned to run from 2005 through 2008. In our opinion, this period was very critical as it witnessed the starting of reforming financial sector as well as by its end 
the global financial crises hit the world. The researcher selected 8 major banks in Egypt that represent public, private sectors and foreign international banks. The 8 banks were selected for the following reasons:

1) The 8 banks all combined capture about $60 \%$ market share of the total Egyptian banking sector based on total assets (CBE, 2007).

2) The sample includes the biggest 2 public sector banks (National Bank of Egypt and Banque Msir).

3) The other 6 banks represent the biggest 6 ranked among all private sector banks based on market share and total assets.

4) Availability of the financial statements and figures.

The banks sample are National bank of Egypt ( NBE ), Banque Misr, Arab African international bank (AAIB), Barclays, HSBC, CIB, NSGB, and Piraeus Bank. The study differentiated between the selected banks based on the nature and structure of the board and existing of the CEO/ Chairman positions, accordingly, study divided the 8 banks into 3 groups. The first Group A, (where the title of CEO is not exist in structure of the said banks), includes National Bank of Egypt and Banque Misr. The second Group B, (where no separation as Chairman serves as CEO -duality), includes NSGB, CIB, and Piraeus Bank. The third Group C, (where CEO and chairman positions are totally separated - non duality), includes Arab African Bank, Barclays, and HSBC.

In each group we gathered and analyzed 3 consecutive years (2005 to 2007) related financial reports, we calculated the ROA \& ROE for each bank separately, then we conducted an average for the entire group for each year and then for the whole 3 years period respectively, finally a comparison between the 3 categories was conducted to reach the final conclusion if separation positions of chairman and CEO would enhance the ROE \& ROA and respectively the financial performance of banks in the Egyptian banking sector. The study samples average total assets represents about $60 \%$ market share of based on total assets of banking sector in Egypt as per CBE 2007 annual report, however number of total banks was limited to only 8 due to the reasons mentioned before .

Group A encompassed 2 major public sector, The National bank of Egypt and Banque Misr, both banks sharing the fact that no CEO position exists in bank structure .Total assets combined for 2 banks amounted LE 367,399 billion representing $39.2 \%$ of total banking sector in Egypt in 2007. As shown on the above table the 3 years average ROA \& ROE for the entire group A were respectively $0.20 \%$, and $6.49 \%$.

Table 2. Average financials for the National bank of Egypt and Banque Misr (Group A, 2005-2007)

\begin{tabular}{lcccccc}
\hline \multicolumn{1}{c}{ Bank Name } & Total & Total & Net & & \\
Assets & ( Market Share ) & Equity & ROA & ROE \\
\hline NBE & 177,716 & $23.3 \%$ & 6,446 & 415 & $0.23 \%$ & $6.44 \%$ \\
Banque Misr & 126,034 & $16.5 \%$ & 3,377 & 221 & $0.18 \%$ & $6.54 \%$ \\
Total & $\mathbf{3 0 3 , 7 5 0}$ & $\mathbf{3 9 . 9 \%}$ & $\mathbf{9 , 8 2 3}$ & $\mathbf{6 3 6}$ & $\mathbf{0 . 2 0 \%}$ & $\mathbf{6 . 4 9 \%}$ \\
\hline
\end{tabular}

Source: Authors (2016)

Group B encompassed 3 private sector banks Commercial International Bank (CIB) National Societe Generale Bank (NSGB), and Piraeus Bank. They have combined total assets LE 96,483 billion representing $10.3 \%$ of total banking sector in Egypt in 2007. The 3 banks shared the fact that its chairman serves as CEO as well. Meaning that chairman combined both authorities of being a chairman and CEO as well (duality). As shown on table 3 years average ROA \& ROE for the entire group B were respectively $1.24 \%$, and $16.89 \%$.

Table 3. Average financials for the Commercial International Bank (CIB) National Societe Generale Bank (NSGB), and Piraeus Bank (Group B, 2005-2007)

\begin{tabular}{lllllll}
\hline Bank Name & Total Assets & ( Market share ) & Total Equity & Net Profit & ROA & ROE \\
NSGB & 31,855 & $4.2 \%$ & 2,066 & 248 & $0.78 \%$ & $12.01 \%$ \\
\hline CIB & 38,582 & $5.1 \%$ & 2,859 & 955 & $2.48 \%$ & $33.41 \%$ \\
Piraeus Bank & 6,516 & $0.9 \%$ & 585 & 31 & $0.47 \%$ & $5.27 \%$ \\
Total & $\mathbf{7 6 , 9 5 4}$ & $\mathbf{1 0 . 1 \%}$ & $\mathbf{5 , 5 0 9}$ & $\mathbf{1 , 2 3 4}$ & $\mathbf{1 . 2 4 \%}$ & $\mathbf{1 6 . 8 9 \%}$ \\
\hline
\end{tabular}

Source:Authors(2016) 
Group C encompassed 3 private sector banks which are Barclays, HSBC and Arab African Bank. Combined total assets for the 3 banks amounted LE 89,455 billion representing $9.5 \%$ of total banking sector in 2007. The 3 banks have separated the clearly the positions of CEO and chairman (non-duality). As shown on table 4 ROA \& ROE for the entire group C were respectively $2.48 \%, 44.43 \%$.

Table 4. Average financials for Barclays, HSBC and Arab African Bank (Group C, 2005-2007)

\begin{tabular}{|c|c|c|c|c|c|c|}
\hline Bank Name & $\begin{array}{l}\text { Total } \\
\text { Assets }\end{array}$ & ( Market Share) & $\begin{array}{l}\text { Total } \\
\text { Equity }\end{array}$ & $\begin{array}{l}\text { Net } \\
\text { Profit }\end{array}$ & ROA & ROE \\
\hline Arab African Bank & 30,094 & $4.0 \%$ & 1,183 & 474 & $1.58 \%$ & $40.08 \%$ \\
\hline Barclays & 12,795 & $1.7 \%$ & 679 & 326 & $2.55 \%$ & $48.04 \%$ \\
\hline HSBC & 19,572 & $2.6 \%$ & 1,441 & 651 & $3.33 \%$ & $45.17 \%$ \\
\hline Total & 62,460 & $8.2 \%$ & $\mathbf{3 , 3 0 3}$ & 1,451 & $2.48 \%$ & $44.43 \%$ \\
\hline
\end{tabular}

Source: Authors (2016)

\section{Results and Discussion}

In order to examine the relationship between Chairman/CEO position and the financial performance of commercial banks in Egypt, Pearson Correlation Coefficient testing was conducted to ensure that study findings are statistically significant. The alpha level $\alpha$ equals $5 \%$. The null hypothesis and the alternative hypothesis were set as following:

- The (non-duality) was set as independent variable; ROA \& ROE were set as 2 dependent variables.

- Null hypothesis $\mathrm{H}_{0}: \mathrm{r}=0$ (no positive relationship between separation chairman \& CEO positions "Non-duality "and enhancing ROA \& ROE in Egyptian banks.)

- The alternative hypothesis H1: $r>0$ (There is a positive correlation between separation chairman \& CEO positions and enhancing ROA \& ROE in Egyptian banks).

- The value of the Pearson Correlation Coefficient (r) was calculated. The Pearson correlation coefficient is a measure of the linear correlation between the two variables which are Chairman/CEO position and the financial performance of commercial banks in Egypt, giving a value between +1 and -1 inclusive, where 1 is total positive correlation, 0 is no correlation, and -1 is total negative correlation. It is widely used as a measure of the degree of linear dependence between two variables. Also, the statistical test was conducted and the results were:

- $\mathrm{r}=.70$ for variable ROA and $\mathrm{r}=.79$ for variable ROE

- Decision rule for rejecting the null hypothesis.

To write the decision rule we had to know the critical value for $r$, with an alpha level of .05 (two-tailed test) as we are not previously sure of the results, and critical value was found .404 .

Reject $\mathrm{H}_{0}$ if $\mathrm{r}>=.404$

Since our calculated value of $r$ and were respectively (.70 and .79) for ROA \& ROE both are greater than the critical value of .404, so we reject the null hypothesis and accept the alternative hypothesis. Hence, the positive correlation between the separation of Chairman /CEO position and enhancing the ROA \& ROE is statistically significant. Based on the findings, the empirical study showed that there is an obvious link and correlation between Non-duality (separation positions of the CEO and chairman) and enhancing ROA \& ROE of the Egyptian banking sector, since in Group $\mathrm{C}$ where clear separation between the two positions was exist, the Group $\mathrm{C}$ performed almost 10 times better the Group A where no CEO position exist in bank's Group, and almost double times better than Group B where chairman serves as CEO. Moreover Group B results where CEO title is exist but occupied by the Chairman were remarkably better than Group A where CEO title is not exist at all. All public sector banks do not have a CEO position in its hierarchies. The study shown that the far and deepening we go towards the full separation between chairman and CEO titles (non-duality) the better ROA \& ROE were conducted.

\section{Conclusion}

Researchers recommends and urges the banking sector to take proper actions to apply and implement a full separation between Chairman and CEO positions in addition urging the central bank of Egypt as the responsible entity for banking sector in Egypt to take necessary actions to direct Egyptian banks to implement full separation between the two posts, as per the study findings this will support enhancing banking corporate governance that most probably will lead to better financial results. Due to the size of the sample the study results should be taken with caution, it is recommended 
for further studies to enlarge and expand the number of banks sample size, additionally more deep financial analysis to examine financial performance since it was limited in this study to ROA \& ROE.

\section{References}

African Development Bank Group. (2012). Evaluation of Policy Based Lending in the African Development Bank, 1999-2009 Case Study: Egypt Financial Sector Reform Programme, http://www.afdb.org/fileadmin/uploads/afdb/Documents/Evaluation-Reports-_Shared-With-OPEV_/Egypt\%20 Financial\%20Sector\%20Case\%20Study\%20FINAL.pdf, accessed 10/31/15.

Arun, T., \& Turner, J. (2004). Corporate Governance of Banks in Developing Economies: Concepts and Issues. Corporate Governance: An International Review, 12(3), 371-377.

Ayuso, S., \& Argandona, A. (2007). Responsible Corporate Governance: Towards a Stakeholders Board of Directors,file:///C:/Users/user/Desktop/corp\%20governance\%20enron\%20of\%20saudi\%20arabia/corprayte\%20 governance\%20responsibilty.pdf, accessed 10/29/15.

Bank for International Settlements. (2006). Basel Committee on Banking Supervision: Enhancing Corporate Governance in Banking Organizations, http://www.bis.org/publ/bcbs122.pdf, accessed 10/29/2015.

Black, B. S., Hasung, J., \& Woochan, K. (2006). Does Corporate Governance Predict Firms' Market Values? Evidence from Korea. Journal of Law, Economics and Organization, 22, 366-413. http://dx.doi.org/10.1093/jleo/ewj018

Caprio, J., \& Levine, R. (2002). Corporate governance in Finance: Concepts and international observations," in Financial Sector Governance: The Roles of the Public and Private Sectors, Eds. R. E. Litan, M. Pomerleano, and V. Sundararajan, Washington, DC: The Brookings Institution, pp. 17-50.

Central Bank of Egypt (CBE). (2006). Annual Report 2006/2007, http://www.cbe.org.eg/NR/rdonlyres/4AD6C723-D352-41E6-8AFE-A0647D7C3375/782/AnnualReport2007E. pdf, accessed 21/10/15.

Central Bank of Egypt (CBE), (2007). Annual Report 2007/2008, http://www.cbe.org.eg/NR/rdonlyres/2F8763CA-8DBD-4BF1-B03E-E06FE6D3E3F6/918/Annual20072008En. pdf, accessed 21/10/15.

Dahya, J., Garcia, L., \& Bommel, J. (2009). One Man Two Hats: What's All the Commotion!, Financial Review, 44(2), 179-212. http://dx.doi.org/10.1111/j.1540-6288.2009.00215.x

Jensen, M. (1993). The Modern Industrial Revolution, Exit and the Failure of Internal Control Systems. Journal of Finance, 48, 831-880. http://dx.doi.org/10.1111/j.1540-6261.1993.tb04022.x

Jensen, M. C. \& Meckling, W. (1976). Theory of the Firm: Managerial Behavior, Agency Costs and Capital Structure. Journal of Financial Economics, 3, 305-360. http://dx.doi.org/10.1016/0304-405X(76)90026-X

Kang, E., \& Zardkoohi, A. (2005). Board Leadership Structure and Firm Performance. Corporate Governance: An International Review, 13(6), 785-799.

Macey, J., \& O’Hara, M. (2003). The Corporate Governance of Banks, Economic Policy Review, 91-107.

Marcinkowska, M. (2012). Corporate Governance in Banks: Problems and Remedies. Financial Assets and Investing Journal, 2, 47-67.

Mehran, H., Morrison, A., \& Joel Shapiro. (2011). Corporate Governance and Banks: What Have We Learned from the Financial Crisis? http://dx.doi.org/10.2139/ssrn.1880009

Narwal, K., \& Jindal, S. (2015). The Impact of Corporate Governance on the Profitability: An Empirical Study of Indian Textile Industry. International Journal of Research in Management, Science \& Technology, 3, 2, 81-85.

Russell Reynolds Associates survey. (2012). Splitting the CEO and Chairman Roles - Yes Or No?, http://www.russellreynolds.com/newsroom/splitting-the-ceo-and-chairman-roles-yes-or-no, accessed 11/4/15.

Todorovic, I. (2013). Impact of Corporate Governance on Performance of Companies. Montenegrin Journal of Economics, 9(2), 47-53.

Tonello, M. (2011). The Corporate Contributions Report. The Conference Board Research Report No. R-1488-11-RR. Available at SSRN: http://ssrn.com/abstract=2032232.

Usui, T. (2003). Corporate Governance of Banking Organizations in the United States and in Japan. Delaware Journal of Corporate Law, 28, 563-597. 